\title{
MAKING OF IRON NUGGET FROM CONCENTRATED IRON SAND USING MINI-SIZED ROTARY KILN
}

\author{
PEMBUATAN NUGET BESI DARI KONSENTRAT PASIR BESI \\ MENGGUNAKAN TUNGKU PUTAR MINI
}

\author{
NURYADI SALEH, SITI ROCHANI and HASUDUNGAN E. MAMBY \\ Research \& Development Centre for Mineral and Coal Technology \\ Jalan Jenderal Sudirman 623 Bandung 40211 \\ Ph. (+6222) 6030483, Fax. (+6222) 6003373 \\ e-mail: nuryadi@tekmira.esdm.go.id
}

\begin{abstract}
The availability of energy becomes a major problem in the construction of iron mineral-based smelter to produce ferrous metals in the form of pig iron. Therefore, it is necessary to develop the Krupp-Renn technology that based on coal as a reducing agent to produce pig iron in the form of nuggets. Such a technology employs a rotary kiln that consumes less energy than other furnaces. In this study, reduction process of iron sand concentrates with coal as the reductant was accomplished in a minisized rotary kiln (0.6 $\mathrm{m}$ diameter and $6 \mathrm{~m}$ length). The process of iron nugget making from iron sand concentrate was conducted in two (2) stages, namely oxidation and reduction processes. The former was accomplished at a temperature above $800^{\circ} \mathrm{C}$ for 2 (two) hours to produce hematite phase. While the later was carried out at $1250-1300^{\circ} \mathrm{C}$ for $6-8$ hours. Both processes produced iron nuggets that contained more than $90 \%$ Fe. The highest Fe content reached $96.49 \%$ Fe. Such a nugget could meet the requirement for steel making.
\end{abstract}

Keywords: iron nugget, rotary kiln, Krupp-Renn technology, concentrated iron sand, oxidation and reduction processes.

\begin{abstract}
ABSTRAK
Ketersediaan energi menjadi masalah utama dalam pendirian smelter berbasis mineral besi untuk menghasilkan produk logam besi dalam bentuk besi wantah, maka teknologi Krupp-Renn berbasis batubara untuk menghasilkan besi wantah dalam bentuk nuget menggunakan tungku putar yang memerlukan sedikit energi dibandingkan dengan tanur, perlu dikembangkan. Pada penelitian ini, dilakukan proses reduksi konsentrat pasirbesi dengan batubara sebagai reduktor dalam tungku putar mini berukuran diameter 0,6 $\mathrm{m}$ dan panjang $6 \mathrm{~m}$. Proses pembuatan nuget besi dari konsentrat pasirbesi dilakukan dalam 2 (dua) tahap, yaitu tahap oksidasi dan reduksi. Tahap pertama dilakukan pada suhu di atas $800^{\circ} \mathrm{C}$ selama 2 (dua) jam untuk menghasilkan fasa hematit. Tahap kedua dilakukan pada suhu $1250-1300^{\circ} \mathrm{C}$ selama 6-8 jam. Dari kedua tahapan proses tersebut dihasilkan produk besi nuget dengan kadar di atas 90\% Fe dan kadar tertinggi mencapai 96.49\%. Besi nuget ini dapat digunakan untuk bahan baku baja.
\end{abstract}

Kata kunci: besi nuget, tungku putar, teknologi Krupp-Renn, konsentrat pasir besi, proses oksidasi dan reduksi.

\section{INTRODUCTION}

Indonesia has an enormous potency of iron ore as well as iron sand to be processed as raw materials of steel. Hence, processing and refining the minerals need to be developed. Some processes are already commercial but require high energy. One of the energy- 
efficient processes to refine iron sand is the direct reduction process i.e. reduction the iron oxide into metallic iron below the smelting temperature. The product is direct reduced iron (DRI). The basic properties and features of DRI are summarized by Anameric dan Kawatra (2007).

Currently, direct reduction process plays an increasingly important role in the iron making industry (Anameric and Kawatra, 2008). It confirms that commercial iron processing at a smaller scale than that of a blast furnace is available, even to the lowest capacity of about 40,000 tons per year of DRI. The advantage of this process is employing lowrank coal as a reductant. The low-rank coal abundantly available in Indonesia. However, the direct reduction operates at $900-1150^{\circ} \mathrm{C}$ and the reduction kinetics are relatively slow so the product output per unit volume is small. Direct reduction process in the rotary kiln known as SL/RN and there are various modifications in accordance with the composition of iron ore minerals that will be processed using SL/RN-Xstrata To accelerate reduction process and increase the capacity of the products, the reduction temperature is needed to be set around $1230-1260^{\circ} \mathrm{C}$. This process is known as the Krupp Renn.

The production capacity of about 450,000 metric tons in the form of nuggets using the technology was developed in the year of 1930 's to process a high-silica-content iron ore. Therefore, the basicity was maintained under acidic conditions in the range of 0.20.3 by adding limestone. The iron ore to be processed could be in the form of pellets, briquettes or lumps with a size of about 2.5 inches. Bituminous coal or coke breeze was used as a reducing agent which is fed continuously into a rotary kiln.

Some researchers studied the iron nuggets making using various mineral composition such as low-grade iron ore with high alumina and sulfur. Guang, Qing-guo dan Jing-song (2015), mentioned that the reduction rate of iron ore pellet would be improved with the increasing of basicity and the pellet could melt better at $1450^{\circ} \mathrm{C}$. The sulfur content of the iron nugget gradually decreased as the basicity increased from 0.6 to 1.2 . The iron nugget could meet the requirement of steel making. In addition, Park dan Jung (2015), studied smelting reduction of high $\mathrm{Al}_{2} \mathrm{O}_{3}$ ores with petroleum coke containing various slags in the temperature range of 1400 to $1500^{\circ} \mathrm{C}$. It was concluded that the final slag composition was important for the ultimate separation of metal and slag. Based on the research conducted by Birol dan Saridede (2013) and Sah dan Dutta (2010), on direct reduction process, the composite of the pellet as a feed of the furnace plays an important role in producing the nugget. The iron nugget produced from the sample with the basicity $\left(\mathrm{CaO} / \mathrm{SiO}_{2}\right)$ of 0.68 has the optimum physical and chemical properties. It was also concluded that a decrease or increase of basicity has a negative effect on the properties of the iron nuggets.

Based on the research conducted by Nogucira et al. (2014), the high temperature caused the gangue minerals of the iron ore to form a very viscous slag (paste form) due to the high silica content. This condition has caused coalescence of the iron formation. The coalescence mechanism that was caused during iron reduction had produced nodules known as luppen or nugget paste that was-trapped in the slag. There are many ways to eliminate the coalescence. One of them is increasing the amount of reducer. However, it might be lower the amount of nugget produced.

Iron ores with a high content of titanium minerals such as iron sand concentrate as found in Indonesia contain about 8-12\% $\mathrm{TiO}_{2}$. It is suitable to employ the Krupp Renn process in which the non-reduced titanium oxide can be separated from the iron nuggets to gain side products. However, sulfur in the coal (reductant) will bind into iron nuggets. Thus, it is necessary required to removing sulfur content first. The high content of $\mathrm{TiO}_{2}$ will raise the melting point of the slag and can minimize the accretion formation. In some circumstances, Krupp Renn technology even can be applied for a high silica iron ore (more than $30 \%$ silica). The product is then fed into a

blast furnace. These types of ores are common in Indonesia, such as lateritic iron ore in Sebuku Island. Therefore, some modifications are needed in applying this technology in order to produce a highmelting-point slag.

Based on the research conducted by Tsuji dan Tachino (2012), the variety of gangue minerals, in both iron and saprolite $\mathrm{Ni}$ ores, 
affect the reduction process. In the iron ore reduction and the production of a ferronickel alloy from Ni-saprolite ore using a rotary kiln, the gangue minerals will cause a ring formation or an accretion on the surface of the refractory wall due to the deposition of complex oxide alloy which has low melting point. This ring will grow thicker with time and eventually disturb reduction process. However, the accretion formation can be minimized using Fuzzy Logic as studied by Mharakurwa, Nyakoe dan Ikua (2014).

Ring formation occurs in the end zone where the reduction of $\mathrm{FeO}$ has a high stability. The formation of complex oxides will be lowering the melting point such as a ternary system of $\mathrm{FeO}-\mathrm{Al}_{2} \mathrm{O}_{3}-\mathrm{SiO}_{2}$ as wustite, fayalite, iron cordierite, hercynite. The existence of these compounds together will be lowering the melting point and cause a sticking on the kiln wall. In some cases, the accretion occurs due to fine materials agglomeration caused by an overly heated kiln in addition to the low ratio of $\mathrm{C} / \mathrm{Fe}$. This condition is also studied by Çamci, Aydin dan Arslan (2002). Table 1 shows the melting points of compounds that are potentially formed in slag and in turn leading to the accretion on the kiln wall.

Accretion could be avoided by selecting raw materials which meet the engineering requirement, i.e. materials with low impurities content, high tumbler index, lowash coal, high coal reactivity, high coal abrasion index, high coal melting point and low swelling and cracking index (Singh and Jain, 2015).

The aim of this research is to study the process of iron nuggets making from iron concentrate through oxidation and reduction processes with variations of basicity and temperature reduction. During the oxidation process, the conversion of titanium magnetite into titanium hematite was observed and the optimum conditions to obtain a high recovery and purity of the products and by-products of the slag (titanium and vanadium) were also studied.

\section{METHODOLOGY}

Iron sand was sampled from Sukabumi, West Java, and then upgraded using magnetic separator into iron sand concentrates. The experiment was divided into two major stages, i.e. oxidation and reduction processes. At the first stage, the iron sand concentrates were oxidized in a rotary kiln for 2 hours with variations of oxidation temperatures, starting from 600 to $1100^{\circ} \mathrm{C}$. The reduction process was performed in a mini-sized rotary kiln performing diameter of $0.6 \mathrm{~m}$ and length of 6 $\mathrm{m}$ to form an iron nugget.

Oxidation and reduction processes were carried out in the same rotary kiln. The experiments were performed in batch. Retention time in a rotary kiln was set for about 2 hours. To obtain 8 hour-retention, the reduction process was carried out four times in a round. The temperature of reduction was $1260^{\circ} \mathrm{C}$.

About $500 \mathrm{~kg}$ oxidized iron sand concentrates approximately $57 \%$ of $\mathrm{Fe}$ content, coal reductant and flux were placed in hopers. Each feed rate was set to maintain the $\mathrm{C} / \mathrm{Fe}$ ratio around 0.7 with varying basicity. Chemical compositions of limestone flux comprised $0.96 \% \mathrm{SiO}_{2}, 0.04 \mathrm{Fe}_{2} \mathrm{O}_{3}, 0.14$ $\% \mathrm{Al}_{2} \mathrm{O}_{3}, 0.15 \% \mathrm{MgO}$ and $55.8 \% \mathrm{CaO}$. The specification of the coal was $39.12 \%$ volatile matter, $15.93 \%$ ash content, $44.95 \%$ fixed carbon and $2.40 \%$ sulfur. Iron sand concentrates were fed into a hopper mixer using a conveyor belt. At the heating process in the rotary kiln, the first batch of iron sand concentrates would go through a preoxidation process at $900^{\circ} \mathrm{C}$ for two hours. Furthermore, the reduction process was carried out at a non-isothermal condition in which the reduction was done at $1050^{\circ} \mathrm{C}$, then it was heated at a temperature of $1150^{\circ} \mathrm{C}$ to reach the final temperature of $1260^{\circ} \mathrm{C}$. Thus, total reduction time was $6-8$ hours. Retention time in a rotary furnace for reduction is about 2 hours. To obtain 8-hour retention, the reduction process is carried out four times in a round using different temperatures, namely $1050^{\circ} \mathrm{C}, 1100^{\circ} \mathrm{C}$, $1150^{\circ} \mathrm{C}$ and $1260^{\circ} \mathrm{C}$ respectively. The product was then taken out from the kiln, quenched and crushed by a jaw crusher. The nugget was separated from its slag using a magnetic separator. The iron content of the nugget varied from $94-97.5 \%$.

The success of the process depends mainly on the feeding stability. The produced raw nugget was then crushed and delivered to a magnetic separator to obtain the iron nugget and slag. 
The composition of the iron sand concentrates is presented in Table 2, while Figure 1 shows a flow diagram of iron nuggets making using a mini-sized rotary kiln. The experiment was conducted at the Center for Mineral Processing at Cipatat, West Java.

Table 1. Melting points of slag composition

\begin{tabular}{cccl}
\hline Phase & Formula & Melting point, ${ }^{\circ} \mathrm{C}$ & \\
\hline Wustite & $\mathrm{FeO}$ & 1369 & \\
Iron & $\mathrm{Fe}$ & 1565 & \\
Silica & $\mathrm{SiO}_{2}$ & 1723 & \\
Fayalite & $2 \mathrm{FeO} . \mathrm{SiO}_{2}$ & 1205 & \\
Gehlenite & $2 \mathrm{CaO} . \mathrm{Al}_{2} \mathrm{O}_{3} \cdot \mathrm{SiO}_{2}$ & 1593 & \\
Anorthite & $2 \mathrm{CaO} . \mathrm{Al}_{2} \mathrm{O}_{3} .2 \mathrm{SiO}_{2}$ & 1553 & \\
Hercynite & $\mathrm{FeO} . \mathrm{Al}_{2} \mathrm{O}_{3}$ & 1547 & \\
Eutectic-1 & $\mathrm{FeO}+27{ }_{0} \mathrm{CaO}$ & 1070 & \\
Eutectic-2 & $2 \mathrm{FeO} . \mathrm{SiO}_{2}+\mathrm{FeO}$ & 1175 & \\
Eutectic-3 & $2 \mathrm{FeO} . \mathrm{SiO}_{2}+\mathrm{SiO}$ & 1180 & SiO \\
2 & 1105 & Olivine tine line \\
Eutectic-4 & $\mathrm{CaO}+\mathrm{SiO}_{2}+\mathrm{FeO}$ & 1070 & Fayalite/cordierite/hercynite \\
Eutectic-5 & $\mathrm{FeO}+\mathrm{Al}_{2} \mathrm{O}_{3}+\mathrm{SiO}_{2}$ & 1165 & Anorthite/calcium silicate \\
Eutectic-6 & $\mathrm{CaO}+\mathrm{Al}_{2} \mathrm{O}_{3}+\mathrm{SiO}_{2}$ & & \\
\hline
\end{tabular}

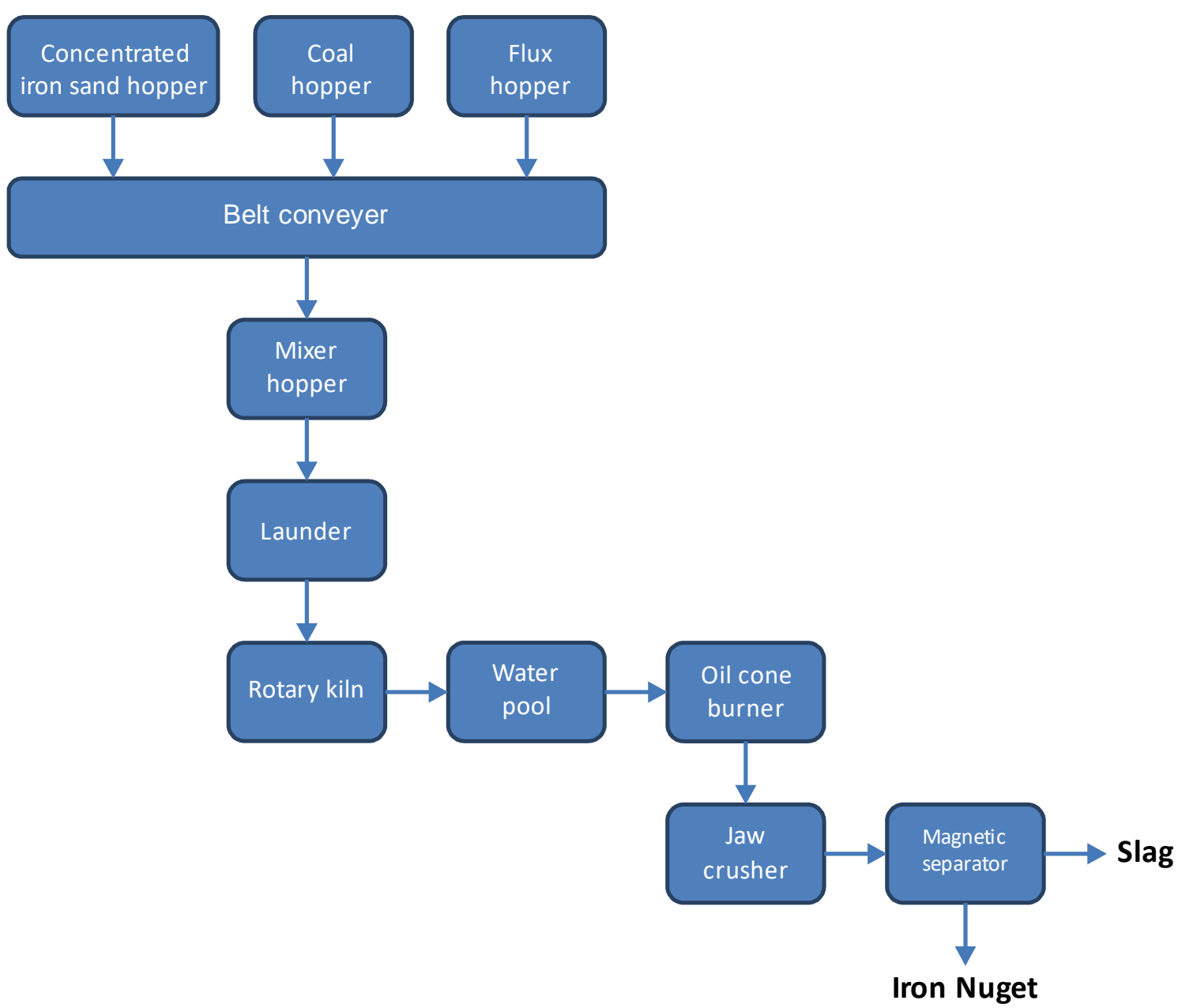

Figure 1. A flow diagram for iron nuggets making in a mini-sized rotary kiln. 
Table 2. Composition of iron sand concentrates

\begin{tabular}{cc}
\hline Compounds & Quantity (\%) \\
\hline $\mathrm{Fe}_{\text {total }}$ & 57.80 \\
$\mathrm{Al}_{2} \mathrm{O}_{3}$ & 4.50 \\
$\mathrm{CaO}$ & 0.31 \\
$\mathrm{MgO}$ & 1.17 \\
$\mathrm{MnO}$ & 0.48 \\
$\mathrm{SiO}$ & 2.66 \\
$\mathrm{TiO}_{2}$ & 9.34 \\
$\mathrm{~V}_{2} \mathrm{O}_{5}$ & 0.36 \\
\hline
\end{tabular}

\section{RESULTS AND DISCUSSIONS}

\section{Oxidation of Iron Sand}

Based on mineralogical analysis, the original iron sand sample contains $80.3 \%$ titanium magnetite, $6.3 \%$ titanium hematite, $0.7 \%$ magnesiocoulsonite (as a source of vanadium oxide), $7.1 \%$ ilmenite, $2.5 \%$ anorthite and $2.3 \%$ diopside. The aim of the oxidation process of the iron sand concentrate prior to reduction is to increase the yield obtained. The oxidation process was carried out by injecting the excess air, varying the oxidation temperature starting from $600^{\circ} \mathrm{C}$ to $1100^{\circ} \mathrm{C}$ with the oxidation time of two hours. Changes in the mineral composition before and after oxidation process with varying temperatures are presented in Table 3. It can be concluded that during the oxidation process, there was the significant number of titanium magnetite converted into titanium hematite. When the heating was started from $600^{\circ} \mathrm{C}$ to $800^{\circ} \mathrm{C}$, the number of titanium magnetite $\left(\mathrm{Fe}_{2.75} \mathrm{Ti}_{0.25} \mathrm{O}_{4}\right)$ converted into titanium hematite $\left(\mathrm{Fe}_{1.831} \mathrm{Ti}_{0.169}\right) \mathrm{O}_{3}$ increased from 15.3 to $74.0 \%$. Moreover, when it was heated from $800^{\circ} \mathrm{C}$ to $1100^{\circ} \mathrm{C}$, the achieved titanium hematite increased from 72.2 to $75.5 \%$ while the amount of remaining titanium magnetite was around 4.9-7.5 \% (Figure 2). This indicates that the optimum temperature for oxidation is $800^{\circ} \mathrm{C}$. Insignificant oxidation change occurred when increasing the temperature above $800^{\circ} \mathrm{C}$.

The oxidation process also caused pseudobrookite. It was indicated from the changes in ilmenite $\left(\mathrm{FeTiO}_{3}\right)$ content (from about $7.1 \%$ to $1-2 \%)$. However, the amount of pseudobrookite $\left(\mathrm{Fe}_{2} \mathrm{TiO}_{5}\right)$ increased up to $8.4 \%$ as shown in Figure 3. Initially, ilmenite was change to pseudo-brookite at temperature $700^{\circ} \mathrm{C}$ to $800^{\circ} \mathrm{C}$ later no change of ilmenite.
As described by Ostrovski, Dewan dan Zhang (2007), in the oxidation reaction of ilmenite, the iron ore migrated faster on the surface and would react with oxygen to form hematite, so that the particles transformed into $\mathrm{TiO}_{2}$ shielded by the $\mathrm{Fe}_{2} \mathrm{O}_{3}$ surface. This mechanism took place at about $700^{\circ} \mathrm{C}$ for 6 hours of heating.

$2 \mathrm{FeTiO}_{3}+1 / 2 \mathrm{O}_{2} \rightarrow \mathrm{Fe}_{2} \mathrm{O}_{3}+2 \mathrm{TiO}_{2}$

This process indicated the presence of oxidized ilmenite to facilitate the dissolution process to produce high-grade $\mathrm{TiO}_{2}$. The formation of rutile started when it was heated at $600^{\circ} \mathrm{C}$ and accompanied by the formation of ferric pseudo-brookite phase $\left(\mathrm{Fe}_{2} \mathrm{TiO}_{5}\right)$.

$\mathrm{Fe}_{2} \mathrm{O}_{3}+\mathrm{TiO}_{2} \rightarrow \mathrm{Fe}_{2} \mathrm{TiO}_{5}$

\section{Reduction Process of Iron Sand Concentrates}

The reduction process was studied by observing the effect of flux added to produce various acidities (The basicity was resulted as the ratio of $(\mathrm{CaO}+\mathrm{MgO})$ to $\left(\mathrm{Al}_{2} \mathrm{O}_{3}+\mathrm{SiO}_{2}\right)$. In this experiment, the values of basicity were $0.18,0.23,0.32$ and 0.41 . The reduction process produced slag. The slag would be passed through magnetization process to separate ferrous metals that mixed on the slag. The composition of the slag after magnetic separation process is presented in Table 4.

Figure 4 shows the effect of basicity to the Fe recovery. The recovery of approximately $89.03 \% \mathrm{Fe}$ was the best achieved at the level of basicity 2.3 and $\mathrm{Fe}$ content in the slag was $13.71 \%$ and $9.94 \% \mathrm{TiO}_{2}$. Krupp Renn process operated in basicity of $2-4$. The weight of the iron nuggets produced in optimal conditions was $53.68 \%$.

Table 4 stated that the experiments performed with basicity 0.41 would produce the $18.01 \% \mathrm{TiO}_{2}$. It is remarkable that the high $\mathrm{TiO}_{2}$ content can be extracted to result in a pure $\mathrm{TiO}_{2}$ product as a by-product of the iron ore reduction process. Consequently, there are two preference conditions in the reduction process based on basicity. First is on basicity of 0.23 (recovery of $89.03 \%$ ). Second, is on basicity of 0.41 with lower nugget recovery (79.10\%). Producing titanium oxide using basicity of 0.41 is the best condition. 
INDONESIAN MINING JOURNAL Vol. 20, No. 1, April 2017 : 59 - 68

Table 3. Mineral composition of the oxidized iron sand concentrate

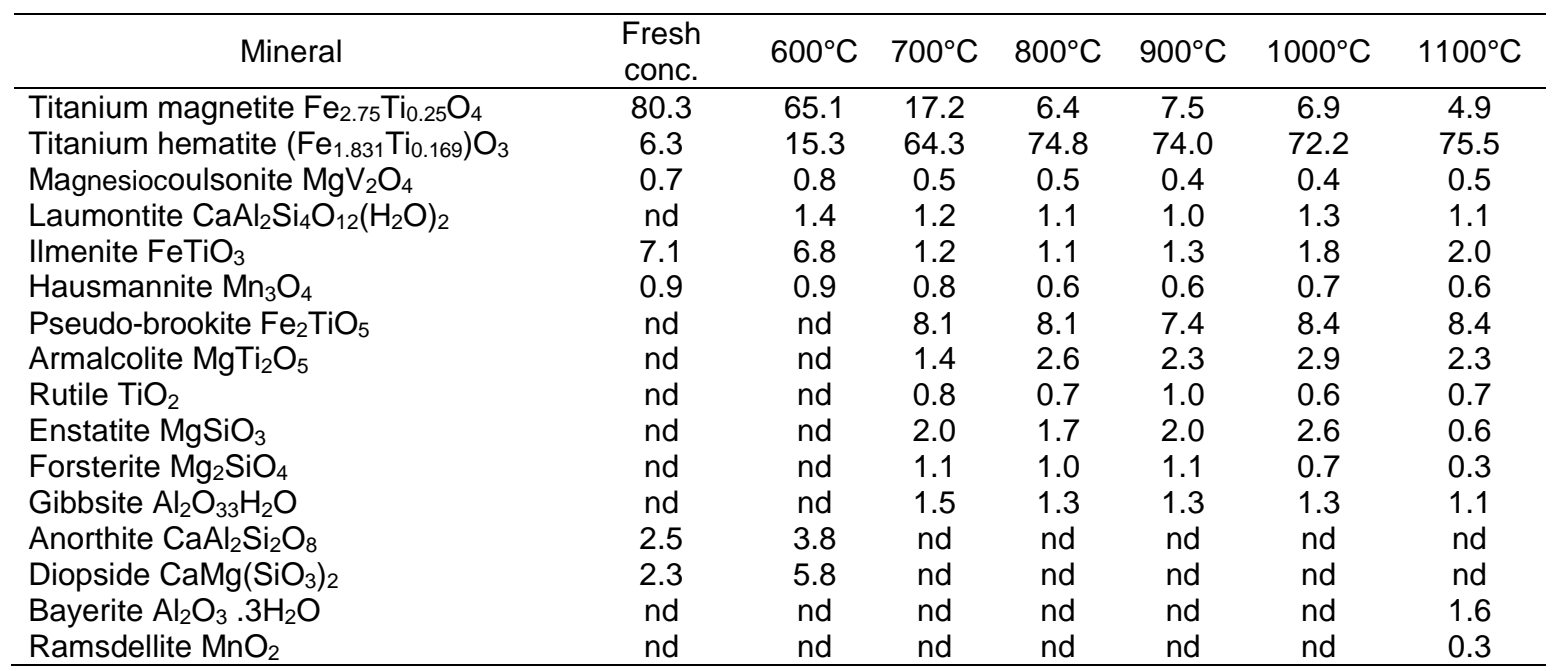

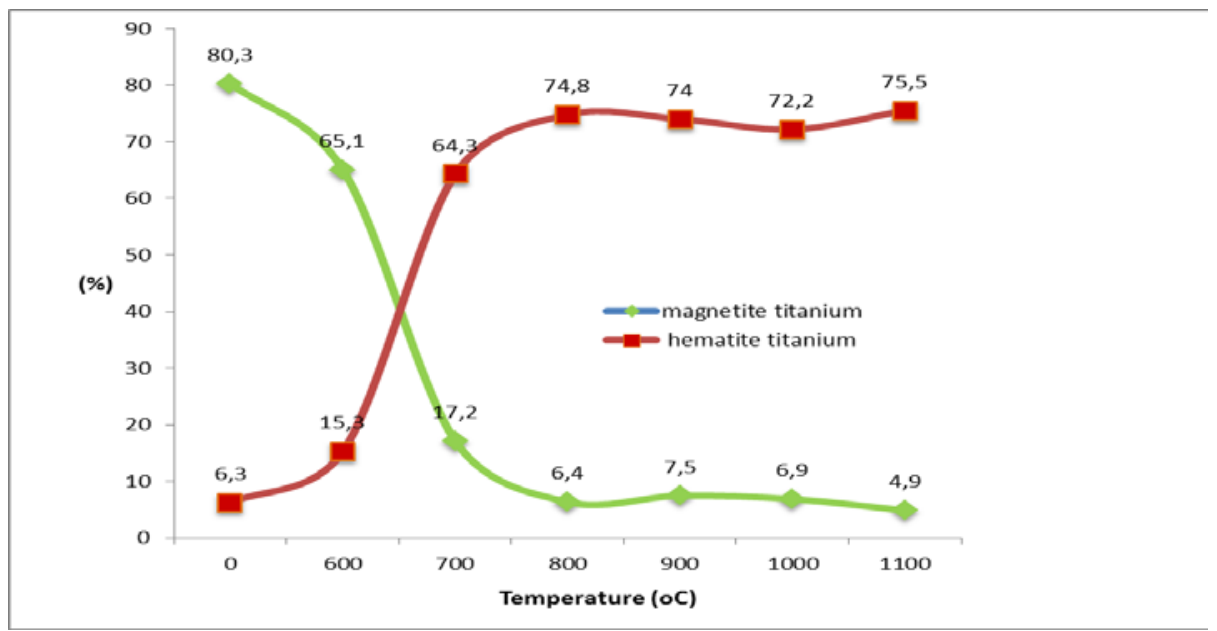

Figure 2. Effect of oxidation temperature on the formation of titanium hematite.

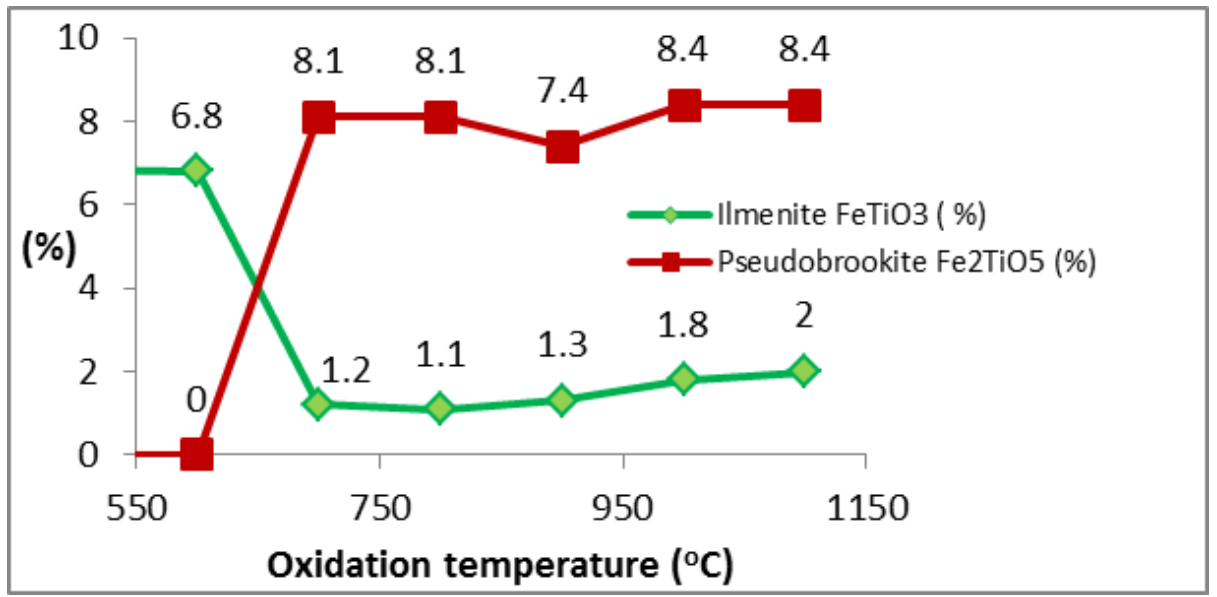

Figure 3. Effect of temperature on the formation of pseudo-brookite 
Table 4. Chemical composition of the slag with varying basicity

\begin{tabular}{|c|c|c|c|c|c|c|}
\hline No. & $\begin{array}{c}\text { Compound } \\
\text { Basicity }\end{array}$ & UNIT & $\begin{array}{c}\text { SLAG-1 } \\
0.18\end{array}$ & $\begin{array}{c}\text { SLAG-2 } \\
0.23\end{array}$ & $\begin{array}{c}\text { SLAG-3 } \\
0.32\end{array}$ & $\begin{array}{c}\text { SLAG-4 } \\
0.41\end{array}$ \\
\hline 1 & Fe (Tot) & $\%$ & 34.69 & 13.71 & 30.65 & 23.99 \\
\hline 2 & $\mathrm{Fe}_{2} \mathrm{O}_{3}$ & $\%$ & 49.61 & 19.59 & 43.83 & 34.27 \\
\hline 3 & $\mathrm{Al}_{2} \mathrm{O}_{3}$ & $\%$ & 23.03 & 31.32 & 19.24 & 13.18 \\
\hline 4 & $\mathrm{BaO}$ & $\%$ & 0.01 & 0.03 & 0.04 & 0.04 \\
\hline 5 & $\mathrm{CaO}$ & $\%$ & 5.92 & 6.93 & 7.90 & 9.38 \\
\hline 6 & Co & $\%$ & 0.01 & 0.01 & 0.01 & 0.01 \\
\hline 7 & $\mathrm{Cr}_{2} \mathrm{O}_{3}$ & $\%$ & 0.12 & 0.09 & 0.25 & 0.02 \\
\hline 8 & $\mathrm{Cu}$ & $\%$ & 0.01 & 0.02 & 0.01 & 0.01 \\
\hline 9 & $\mathrm{~K}_{2} \mathrm{O}$ & $\%$ & 0.28 & 0.41 & 0.25 & 0.07 \\
\hline 10 & $\mathrm{MgO}$ & $\%$ & 4.60 & 4.73 & 3.99 & 3.4 \\
\hline 11 & $\mathrm{MnO}$ & $\%$ & 0.94 & 0.69 & 0.43 & 0.68 \\
\hline 12 & $\mathrm{Na}_{2} \mathrm{O}$ & $\%$ & 0.32 & 0.64 & 2.26 & 0.07 \\
\hline 13 & $\mathrm{Ni}$ & $\%$ & 0.08 & 0.01 & 0.09 & 0.01 \\
\hline 14 & $\mathrm{P}_{2} \mathrm{O}_{5}$ & $\%$ & 0.14 & 0.19 & 0.13 & 0.08 \\
\hline 15 & $\mathrm{~Pb}$ & $\%$ & 0.08 & 0.18 & 0.06 & 0.01 \\
\hline 16 & $\mathrm{SiO}_{2}$ & $\%$ & 11.12 & 19.94 & 17.37 & 18.01 \\
\hline 17 & $\mathrm{TiO}_{2}$ & $\%$ & 9.94 & 9.59 & 8.47 & 18.15 \\
\hline 18 & $\mathrm{~V}_{2} \mathrm{O}_{5}$ & $\%$ & 0.32 & 0.35 & 0.03 & 0.01 \\
\hline 19 & $\mathrm{Zn}$ & $\%$ & 0.03 & 0.15 & 0.01 & 0.02 \\
\hline
\end{tabular}

Table 5. Fe recovery in various basicity values

\begin{tabular}{lccccc}
\hline \multicolumn{1}{c}{ Basicity } & Unit & 0.18 & 0.23 & 0.32 & 0.41 \\
\hline Fe Recovery & $\%$ & 62.71 & 89.03 & 69.64 & 78.10 \\
Mass & $\%$ & 37.80 & 53.68 & 42.68 & 47.17 \\
\hline
\end{tabular}

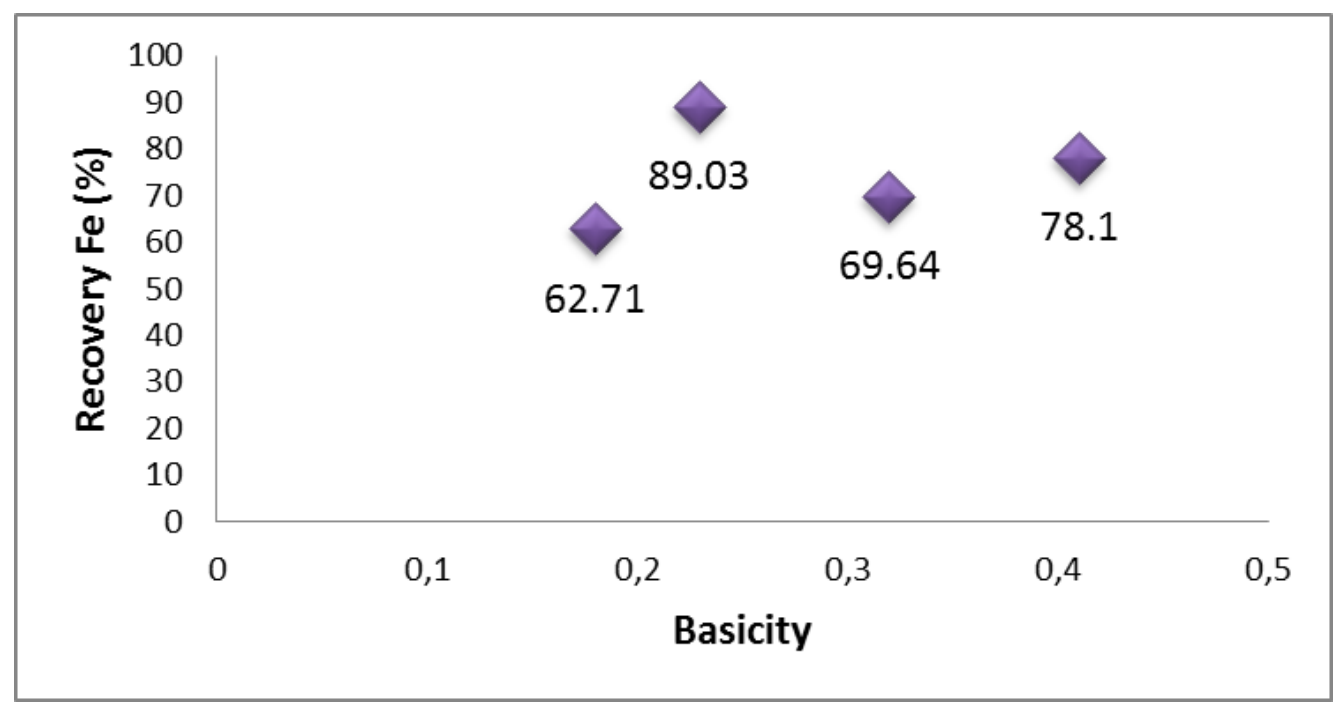

Figure 4. Effect of basicity on Fe recovery

The result of XRD analysis on the slag with a basicity of 0.23 is presented in Table 6 . The minerals that predicted to form an accretion due to its low melting points, such as $3.2 \%$ nepheline, $6.3 \%$ augite and $4.7 \%$ pargasite are clearly detected. The total sum of those minerals are about $14.2 \%$ and considered as high enough to disturb the reduction process in the rotary kiln. At basicity of 0.23 , the iron was reduced to build up a ring of slag on the rotary kiln.

It is clear that minerals containing slag were predicted to form an accretion due to its low 
melting point namely $3.2 \%$ nepheline, $6.3 \%$ augite and $4.7 \%$ pargasite. Total accretion is $14.2 \%$. This number is considered high. The accretion can be formed faster to interrupt the reduction process in the rotary kiln.

The quality of iron nuggets product from the reduction process is presented in Table 7 . The carbon, sulphur and phosphor contents are $2.48 \%-3.95 \% \mathrm{C}, 0.32 \%-0.54 \% \mathrm{~S}$ and $0.06 \%-0.08 \%$ respectively.These elements content can be categorized as high for the iron nugget, which is the characteristic of Krupp-Renn process. Vanadium and titanium in the form of oxides are present in the slag.

After the reduction process finished, the slag can be separated. However, the slag still contains iron nugget and it is necessary to be separated. The slag was passed to a magnetic separator to remove the iron nugget. The picture of the slag can be seen in Figure 5.

Table 6. The minerals composition in the slag

\begin{tabular}{lccc}
\hline \multicolumn{1}{c}{$\mathrm{Minerals}$} & & Weight & Melting Point ${ }^{\circ} \mathrm{C}$ \\
\hline Hercynite $\mathrm{FeAl}_{2} \mathrm{O}_{4}$ & $\%$ & 14.1 & 1780 \\
Anorthite $\mathrm{CaAl}_{2}\left(\mathrm{SiO}_{4}\right)_{2}$ & $\%$ & 13 & 1553 \\
Spinel $\mathrm{MgAl}_{2} \mathrm{O}_{4}$ & $\%$ & 13.4 & 2135 \\
Perovskite $\mathrm{CaTiO}_{3}$ & $\%$ & 7.8 & 1975 \\
Nepheline $\mathrm{K} \mathrm{Na}_{3}(\mathrm{AlSiO})_{4}$ & $\%$ & 3.2 & 1020 \\
Titanium magnetite & $\%$ & 11.9 & 1800 \\
$\mathrm{Fe}_{2.75} \mathrm{Ti}_{0.25} \mathrm{O}_{4}$ & $\%$ & 1.1 & 1800 \\
Ilmenite $\mathrm{FeTiO}_{3}$ & $\%$ & 6.3 & 1200 \\
Augite $\mathrm{CaMg}_{0.7} \mathrm{Al}_{0.16} \mathrm{Si}_{1.7} \mathrm{O}_{6}$ & $\%$ & & \\
Pargasite & & & 1100 \\
NaCa $\mathrm{Mg}_{4} \mathrm{Al}_{3} \mathrm{Si}_{6} \mathrm{O}_{22}(\mathrm{OH})_{2}$ & $\%$ & 4.7 & 1670 \\
Quarts $\mathrm{SiO}_{2}$ & $\%$ & 2.5 & 1850 \\
Mullite $\mathrm{Al}_{2.15} \mathrm{Si}_{1.41} \mathrm{O}_{9.7}$ & $\%$ & 9.6 & 1435 \\
Cordierite $\mathrm{Mg}_{2} \mathrm{Al}_{4} \mathrm{Si}_{5} \mathrm{O}_{18}$ & $\%$ & 1.1 & 2044 \\
Corundum $\mathrm{Al}_{2} \mathrm{O}_{3}$ & $\%$ & 8.9 & \\
\hline
\end{tabular}

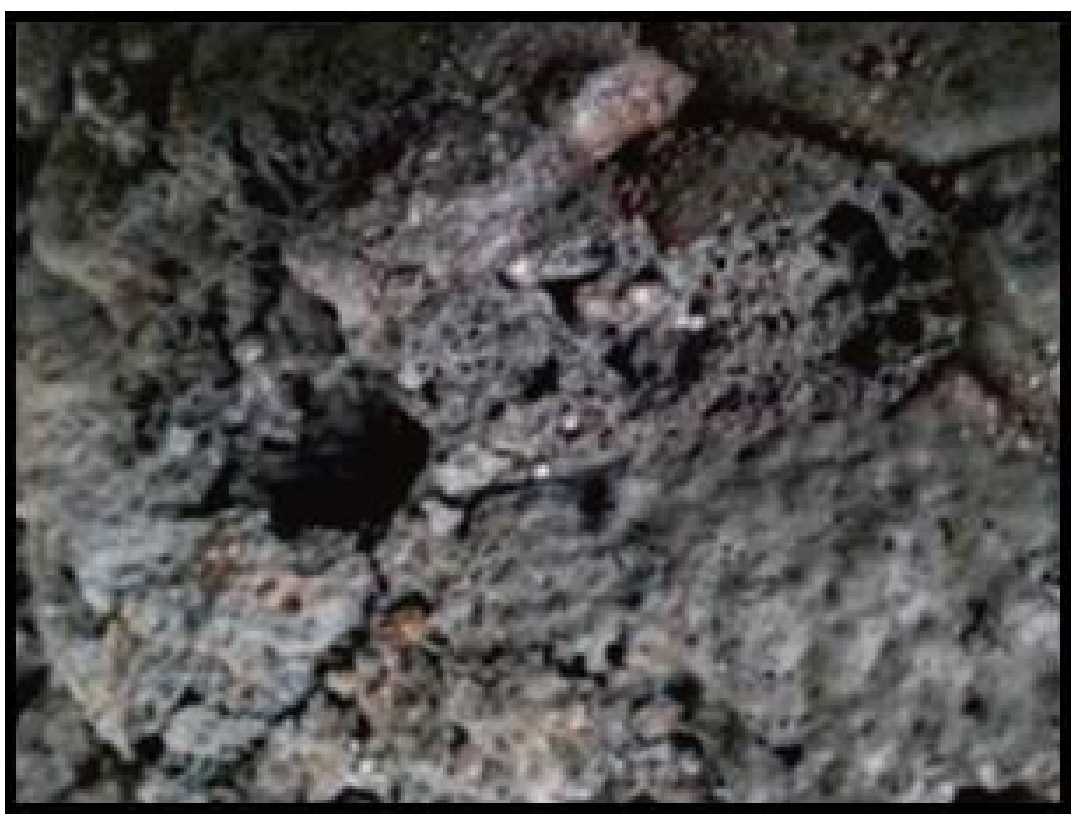

Figure 5. Iron nugget-containing slag showing nugget particles trapped 
Making of Iron Nugget from Concentrated ... Nuryadi Saleh, Siti Rochani and Hasudungan E. Mamby

Table 7. The chemical composition of iron nuggets in different samples

\begin{tabular}{cccccccc}
\hline Element & Unit & Code-1 & Code-2 & Code-3 & Code-4 & Code-5 & Code-6 \\
\hline $\mathrm{C}$ & $\%$ & 3.14 & 2.72 & 3.95 & 2.84 & 2.72 & 2.48 \\
$\mathrm{Si}$ & $\%$ & 0.065 & 0.15 & 0.34 & 0.21 & 0.158 & 0.052 \\
$\mathrm{~S}$ & $\%$ & 0.33 & 0.49 & 0.316 & 0.329 & 0.499 & 0.538 \\
$\mathrm{P}$ & $\%$ & 0.065 & 0.06 & 0.078 & 0.072 & 0.0606 & 0.108 \\
$\mathrm{Mn}$ & $\%$ & 0.0697 & 0.028 & 0.312 & 0.369 & 0.827 & 0.061 \\
$\mathrm{Ni}$ & $\%$ & 0.0069 & 0.012 & 0.0062 & 0.00437 & 0.012 & 0.0061 \\
$\mathrm{Cr}$ & $\%$ & 0.022 & 0.065 & 0.051 & 0.0577 & 0.064 & 0.0211 \\
$\mathrm{Mo}$ & $\%$ & 0.01 & 0 & 0.011 & 0.0081 & 0.008 & 0.0083 \\
$\mathrm{~V}$ & $\%$ & 0.019 & 0.07 & 0.073 & 0.082 & 0.0748 & 0.019 \\
$\mathrm{Cu}$ & $\%$ & 0.13 & 0.129 & 0.116 & 0.109 & 0.129 & 0.129 \\
$\mathrm{~W}$ & $\%$ & 0.0037 & 0 & 0.011 & 0.0022 & 0 & 0 \\
$\mathrm{Ti}$ & $\%$ & 0.0263 & 0.071 & 0.08 & 0.066 & 0.071 & 0.01 \\
$\mathrm{Sn}$ & $\%$ & 0.012 & 0.0012 & 0.002 & 0.0015 & 0.0011 & 0.00198 \\
$\mathrm{Al}$ & $\%$ & 0.057 & 0.0046 & 0.049 & 0.01 & 0.004 & 0.00626 \\
$\mathrm{~Pb}$ & $\%$ & 0.016 & 0.00885 & 0.019 & 0.013 & 0.00885 & 0.007 \\
$\mathrm{Sb}$ & $\%$ & 0.0024 & 0.00054 & 0.006 & 0.00072 & 0.00054 & 0 \\
$\mathrm{Nb}$ & $\%$ & 0.0068 & 0.0096 & 0.14 & 0.0081 & 0.0096 & 0.0445 \\
$\mathrm{Mg}$ & $\%$ & 0.00381 & 0.00061 & 0.00451 & 0.0019 & 0.0006 & 0.0026 \\
$\mathrm{Zn}$ & $\%$ & 0.2265 & 0.0286 & 0.021 & 0.022 & 0.011 & \\
$\mathrm{Fe}$ & $\%$ & 95.98 & 95.951 & 94.40 & 95.79 & 95.31 & 96.49 \\
\hline
\end{tabular}

The size of the iron nuggets can be seen in Figure 6 . The size of the nuggets product ranges from $2 \mathrm{~mm}$ to $2 \mathrm{~cm}$. Actually, the best size for steelmaking is around $3 \mathrm{~mm}$. If the size is too fine, the material will fly during heated in the furnace. The fine nugget cannot suck out to stack because it was trapped in slag. Fine nugget particle was liberated after milling. Thus the nugget should be briquetted prior to feeding into the furnace.

\section{CONCLUSION}

The process of nuggets making using Krupp-Renn process was accomplished by oxidation and reduction process stages. In the oxidation process, titanium magnetite converts into titanium hematite. It is noted that basicity of the feed has a very important role in this process to gain higher recovery as well as to gain by-products which can be extracted from the slag.

\section{ACKNOWLEDGEMENTS}

The authors wish to acknowledge to PT Sumber Baja Prima for providing the iron sand concentrates. The authors also wish to express gratitude to the MEMR for funding the research as well as our colleagues who have assisted the research.

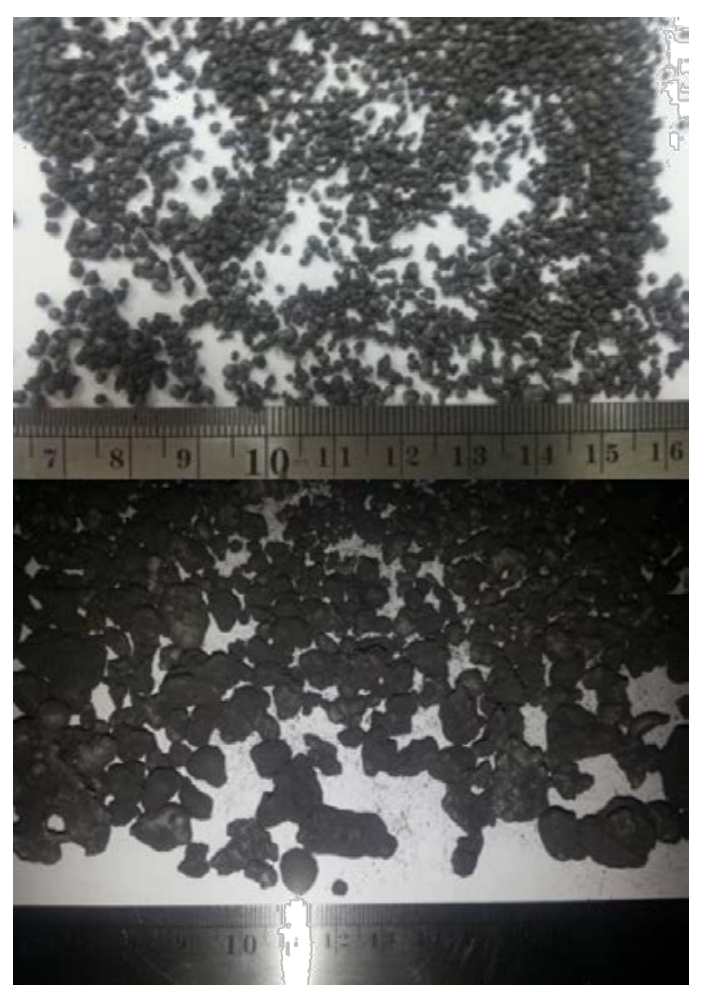

Figure 6. Size of the iron nuggets 


\section{REFERENCES}

Anameric, B. and Kawatra, S. K. (2007) "Properties and features of direct reduced iron," Mineral Processing and Extractive Metallurgy Review, 28(1), pp. 59-116. doi: 10.1080/08827500600835576.

Anameric, B. and Kawatra, S. K. (2008) "Direct iron smelting reduction processes," Mineral Processing and Extractive Metallurgy Review, 30(1), pp. 1-51. doi: 10.1080/08827500802043490.

Birol, B. and Saridede, M. N. (2013) "The effect of reduction parameters on iron nugget production from composite pellets," Mineral Processing and Extractive Metallurgy Review, 34(4), pp. 195-201. doi: 10.1080/08827508.2012.695305.

Çamci, L., Aydin, S. and Arslan, C. (2002) "Reduction of iron oxides in solid wastes generated by steelworks," Turkish Journal of Engineering and Environmental Sciences, 26(1), pp. 3744

Guang, W., Qing-guo, X. and Jing-song, W. (2015) "Preparation of iron nugget using low grade iron ore of high alumina and sulphur," Iron and steel, 50(11), pp. 1420. doi: 10.13228/10.13228/j.boyuan.issn0449749x.20150004.

Mharakurwa, E. ., Nyakoe, G. N. and Ikua, B. W. (2014) "Accretion control in sponge iron production kiln using fuzzy logic," Innovative Systems Design and Engineering, 5(7), pp. 41-51.

Nogucira, A., Takano, C., Mourão, M. and Pillihuaman, A. (2014) "Effects of reducer and slag concentrations in the iron-carbon nuggets coalescence in self reducing processes," in TMS Annual Meeting, pp. 247-254. Available at: http://www.scopus.com/inward/record.url ?eid=2-s2.0-

84899831718\&partnerID=tZOtx3y1.

Ostrovski, O., Dewan, M. A. and Zhang, G. (2007) "Synthesis of titanium oxycarbide by carbothermal reduction of titania," in Niinomi, M. and Gakkai, N. K. (eds.) Ti2007 Science and Technology: proceedings of the 11th World Conference on Titanium (JIMIC5). Kyoto, p. 851.

Park, J.-O. and Jung, S.-M. (2015) "Metal/Slag separation behavior of CCA with various slag systems and effect of slag composition on the content of sulfur and phosphorus in iron nugget," ISIJ International, 55(8), pp. 1625-1632. doi: 10.2355/isijinternational.ISIJINT-2015118.

Sah, R. and Dutta, S. K. (2010) "Effects of binder on the properties of iron ore-coal composite pellets," Mineral Processing and Extractive Metallurgy Review, 31(2), pp. 73-85. doi: 10.1080/08827500903404732.

Singh, A. and Jain, P. (2015) "A study on the accretion formation in DRI kilns and possible ways for its reduction," IOSR Journal of Mechanical and Civil Engineering (IOSR-JMCE), 12(6), pp. 98-103.

Tsuji, H. and Tachino, N. (2012) "Ring formation in the smelting of saprolite Ni-ore in a rotary kiln for production of ferro-nickel alloy: examination of the mechanism," ISIJ International, 52(11), pp. 19511957.

doi: 